\title{
PENDEKATAN KEADILAN RESTORATIF: UPAYA MELIBATKAN PARTISIPASI KORBAN DAN PELAKU SECARA LANGSUNG DALAM PENYELESAIAN PERKARA PIDANA
}

\author{
Nefa Claudia Meliala \\ email: nefa.meliala@gmail.com
}

\begin{abstract}
From our understanding of ius poenale and ius puniendi, crime logically is simply considered as any offense directed against the state. In other words, conflict between offender and the State. It follow that justice is related to number of cases processed and punishment served. From this perspective, the criminal justice system disregards victims' and offenders's needs for closure and personal justice. The restorative justice system offers an alternate approach which may compensate the shortcomings of the existing criminal justice system that is by opening up the possibility of victims and offenders participation.
\end{abstract}

Keywords: restorative justice, the participation of victims and perpetrators, the completion of the criminal case

\begin{abstract}
Abstrak
Dari pemahaman umum tentang ius poenale dan ius puniendi, tindak pidana dipahami sebagai serangan terhadap Negara. Dengan kata lain, konflik antara pelaku kejahatan dengan negara. Keadilan, dari sudut pandang ini, dikaitkan pada jumlah perkara yang diproses dan pidana yang dijatuhkan. Dalam sistem peradilan pidana seperti ini, korban dan pelaku tidak banyak berperan dan tidak terbuka ruang bagi korban dan pelaku untuk mencari keadilan yang lebih personal. Pendekatan keadilan restoratif hadir sebagai alternatif mekanisme penyelesaian perkara pidana diharapkan dapat menutupi kekurangan yang terdapat dalam sistem peradilan pidana tersebut dengan cara melibatkan partisipasi korban dan pelaku secara langsung.
\end{abstract}

Kata kunci: keadilan restoratif, partisipasi korban dan pelaku, penyelesaian perkara pidana

\section{Pendahuluan}

Salah satu kelemahan dari sistem peradilan pidana yang saat ini berjalan adalah tidak dilibatkannya partisipasi korban dan pelaku secara langsung dalam penyelesaian perkara. Sistem peradilan pidana seringkali dianggap tidak cukup mewakili aspirasi korban dan sanksi pidana yang dijatuhkan juga dianggap tidak memberikan keuntungan yang dapat dirasakan secara langsung baik oleh korban maupun pelaku. Persoalan ini kemudian berujung pada ketidakpuasan korban dan 
pelaku terhadap bekerjanya sistem peradilan pidana. Pendekatan keadilan restoratif yang justru mengedepankan keterlibatan korban dan pelaku secara langsung hadir sebagai respon atas persoalan tersebut. ${ }^{1}$

Mengacu pada persoalan tersebut diatas, beberapa hal yang akan disoroti dalam tulisan ini adalah sebagai berikut:

1. Perbedaan pemahaman terhadap tindak pidana dan keadilan dalam sistem peradilan pidana dan pendekatan keadilan restoratif yang pada akhirnya akan menjelaskan mengapa dalam sistem peradilan pidana korban dan pelaku memang tidak banyak berperan, lain halnya dengan pendekatan keadilan restoratif.

2. Beberapa alternatif mekanisme penerapan pendekatan keadilan restoratif baik di dalam maupun di luar sistem peradilan pidana dengan melibatkan korban dan pelaku secara langsung dalam penyelesaian perkara pidana yang berujung dengan perdamaian.

3. Undang-undang belum secara jelas mengatur mengenai kekuatan hukum atas kesepakatan perdamaian antara pelaku dan korban dan kewenangan masingmasing subsistem baik di dalam sistem peradilan pidana (polisi, jaksa, hakim) maupun diluar sistem peradilan pidana (lembaga adat, masyarakat) untuk menerapkan pendekatan keadilan restoratif dalam hal terjadinya tindak pidana.

4. Penerapan pendekatan keadilan restoratif merupakan salah satu alternatif mekanisme penyelesaian perkara pidana tertentu yang dapat digunakan untuk menutupi kekurangan yang terdapat dalam sistem peradilan pidana.

\footnotetext{
${ }^{1}$ United Nations Office on Drugs and Crime, Handbook on Restorative Justice Programmes 5, (United Nation, New York, 2006), http://www.unodc.org/pdf/criminal justice/0656290 Ebook.pdf In many countries, dissatisfaction and frustration with the formal justice system or a resurging interest in preserving and strengthening customary law and traditional justice practices have led to calls for alternative responses to crime and social disorder. Many of these alter natives provide the parties involved, and often also the surrounding community, an opportunity to participate in resolving conflict and addressing its consequences. Restorative justice programmes are based on the belief that parties to a conflict ought to be actively involved in resolving it and mitigating its negative consequences.
} 


\section{Dari Sistem Peradilan Pidana ke Pendekatan Keadilan Restoratif: Perubahan Perspektif Terhadap Pengertian Tindak Pidana dan Keadilan}

Sebagai konsekuensi logis dari pemikiran bahwa negara melalui organorgan atau alat-alat kekuasannya memiliki kewenangan untuk menentukan perbuatan-perbuatan apa saja yang dilarang atau diharuskan untuk dilakukan (hukum pidana dalam arti objektif (ius poenale)) sekaligus berwenang untuk menjatuhkan hukuman sesuai dengan yang telah ditentukan undang-undang terhadap setiap orang yang melakukan perbuatan yang dilarang atau tidak melakukan perbuatan yang justru diharuskan untuk dilakukan (hukum pidana dalam arti subjektif (ius puniendi)) ${ }^{2}$, dalam sistem peradilan pidana, tindak pidana kemudian dipahami sebagai suatu serangan terhadap negara. ${ }^{3}$ Dengan kata lain, kejahatan dipandang sebagai konflik antara pelaku kejahatan dengan negara. ${ }^{4}$

Negara dalam hal ini dianggap mengalami suatu serangan dari pelaku tindak pidana sebagai akibat dari telah dilanggarnya aturan hukum pidana positif (peraturan perundang-undangan pidana) yang telah ditetapkan negara melalui pembentuk undang-undang 5 , sehingga aparat penegak hukum baik polisi maupun jaksa yang juga merupakan representasi negara berkewajiban untuk memproses pelanggaran tersebut sesuai aturan hukum pidana yang berlaku. Sejalan dengan

2 Jan Remmelink, Hukum Pidana; Komentar atas Pasal-Pasal Terpenting dari Kitab UndangUndang Hukum Pidana Belanda dan Padanannya dalam Kitab Undang-Undang Hukum Pidana Indonesia 1-3, (Gramedia Pustaka Utama, Jakarta, 2003). Lihat juga P.A.F Lamintang, Dasar Dasar Hukum Pidana Indonesia 3-5 (Citra Aditya Bakti, Bandung, 1996). A.Z . Abidin dan Andi Hamzah, Hukum Pidana Indonesia 5-6, (Yarsif Watampone, Jakarta, 2010). Sudarto, Hukum Pidana I 10, (Yayasan Sudarto, Semarang, Fakultas Hukum Undip Semarang,, 1990).

3 Eva Achjani Zulfa, Reparasi dan Kompensasi Korban Dalam Restorative Justice 28, (Lembaga Perlindungan Saksi dan Korban dan Departemen Kriminologi FISIP UI, Jakarta, 2011). Lihat juga Mardjono Reksodiputro, Bunga Rampai Permasalahan Dalam Sistem Peradilan Pidana, Kumpulan Karangan Buku Kelima 1, (Pusat Pelayanan Keadilan dan Pengabdian Hukum Lembaga Kriminologi Universitas Indonesia, Jakarta, 2007). Mardjono Reksodiputro berpendapat bahwa hukum pidana dilihat sebagai reaksi terhadap perbuatan ataupun orang yang telah melanggar norma-norma moral dan hukum dan karena itu telah mengancam dasardasar pemerintahan, hukum, ketertiban dan kesejahteraan sosial. Dalam pidato pengukuhan Guru Besar Tetap Ilmu Hukum di Fakultas Hukum Universitas Indonesia, Jakarta, 30 Oktober 1993, beliau menyatatakan bahwa para pelaku kejahatan dianggap telah tidak memperdulikan kesejahteraan umum, keamanan dan hak milik orang lain.

${ }^{4}$ Eva Achjani Zulfa, supra catatan no. 3.

5 Mardjono Reksodiputro, supra catatan no. 3. 
pemahaman itu, keadilan kemudian dipahami sebagai penjatuhan hukuman yang tentunya juga dilakukan oleh negara melalui alat kekuasannya (dalam hal ini hakim) kepada pelaku tindak pidana dalam hal dakwaan atau tuduhan jaksa kepada pelaku terbukti secara hukum. ${ }^{6}$ Terlihat bahwa paradigma yang dibangun dalam sistem peradilan pidana saat ini adalah bagaimana negara harus memainkan peranannya berdasarkan kewenangan atau otoritas yang dimilikinya untuk mengatur warga negara melalui organ-organnya. ${ }^{7}$

Karakteristik hukum pidana sebagai hukum publik yang mengatur hubungan antara negara dengan individu, salah satunya ditandai dengan hak dan kewajiban korban dalam sistem peradilan pidana yang diambil alih sepenuhnya oleh negara melalui alat kekuasaannya, dalam hal ini polisi dan jaksa. ${ }^{8}$ Konsekuensinya, korban memang tidak memiliki banyak peran dalam sistem peradillan pidana karena polisi dan jaksa sebagai representasi atau perwakilan negara yang "diserang" dalam konteks terjadinya tindak pidana dianggap telah bertindak untuk mewakili kepentingan korban dalam rangka memperoleh keadilan. Sifat publik hukum pidana yang memperlihatkan betapa dominannya peran negara melalui alat-alat kekuasannya berimplikasi terhadap tidak diberikannya ruang yang cukup baik bagi korban maupun pelaku untuk menyuarakan apa yang sebetulnya menjadi aspirasinya yang boleh jadi berbeda dengan apa yang didakwakan atau dituntut jaksa dalam surat dakwaan dan surat

6 Ringkasan Disertasi, Eva Achjani Zulfa, Keadilan Restoratif di Indonesia (Studi Tentang Kemungkinan Penerapan Pendekatan Keadilan Restoratif Dalam Praktek Penegakan Hukum Pidana), Fakultas Hukum Pogram Studi Ilmu Hukum Kekhususan Sistem Peradilan Pidana Universitas Indonesia, Depok, 20 Juni 2009 (tidak dipublikasi). Lihat juga J.M. van Bemmelen, Strafvordering, Leerboek van het Ned 1, (Martinus Nijhoft, Strafprocesrecht. s-Gravaenhage, 195) dalam Andi Hamzah, Hukum Acara Pidana Indonesia 6, (Sinar Grafika, Jakarta, 2008).

7 Eva Achjani Zulfa, supra catatan no. 3, pada 27.

8 P.A.F Lamintang, Dasar Dasar Hukum Pidana Indonesia 14, (Citra Aditya Bakti, Bandung, 1996). Sifat hukum pidana sebagai hukum publik tampak jelas dari kenyataan-kenyataan antara lain:

a. Bahwa sifatnya yang dapat dihukum dari seseorang yang telah melakukan tindak pidana itu tetap ada, walaupun tindakannya itu telah mendapat persetujuan terlebih dahulu dari korbannya, dan

b. Bahwa penuntutan menurut hukum pidana itu tidak digantungkan pada keinginan dari orang yang telah dirugikan oleh suatu tindak pidana yang telah dilakukan orang lain. 
tuntutannya dengan mengacu pada proses penyidikan yang telah berlangsung sebelumnya. ${ }^{9}$

Sementara itu, sistem peradilan pidana dapat digambarkan secara singkat sebagai suatu sistem yang bertujuan untuk menanggulangi kejahatan, salah satu usaha masyarakat untuk mengendalikan terjadinya kejahatan agar berada dalam batas-batas toleransi yang dapat diterima. ${ }^{10}$ Selain bertujuan untuk mencegah masyarakat menjadi korban kejahatan dan berusaha agar mereka yang pernah melakukan kejahatan tidak mengulangi lagi perbuatannya, salah satu tujuan sistem peradilan pidana adalah untuk menyelesaikan kejahatan yang terjadi sehingga masyarakat puas bahwa keadilan telah ditegakkan dan yang bersalah dipidana. ${ }^{11}$ Oleh karena itu, keadilan kemudian dipahami sebagai penjatuhan hukuman terhadap pelaku dalam hal dakwaan atau tuduhan terbukti secara hukum.

Restorative justice atau yang sering diterjemahkan menjadi keadilan restoratif merupakan suatu model pendekatan dalam upaya penyelesaian perkara pidana sebagai respon terhadap sistem peradilan pidana yang dianggap tidak dapat menampung aspirasi pelaku dan korban. ${ }^{12}$ Apa yang membuat pendekatan keadilan restoratif ini menjadi berbeda jika dibandingkan dengan sistem peradilan pidana adalah pendekatan ini mengedepankan konsep mediasi dan rekonsiliasi sebagai mekanisme penyelesaian sengketa atau konflik dalam hal terjadinya tindak pidana, sesuatu yang selama ini tidak dikenal dalam sistem peradilan pidana. ${ }^{13}$

9 Eva Achjani Zulfa, Konsep Dasar Restorative Justice, Pelatihan Hukum Pidana dan Kriminologi, Asas-Asas Hukum Pidana dan Kriminologi serta Perkembangannya Dewasa ini, Universitas Gajah Mada, Yogyakarta, 23-27 Februari 2014 (tidak dipublikasi).

Lihat juga Eva Achjani Zulfa, Mediasi Penal: Perkembangan Kebijakan Hukum Pidana, Pascasarjana Fakultas Hukum Universitas Indonesia (tidak dipublikasi).

10 Mardjono Reksodiputro, Mengembangkan Pendekatan Terpadu Dalam Sistem Peradilan Pidana, Pra Seminar Hukum Nasional V, Jakarta, 21 Januari 1986 (tidak dipublikasi) dimuat kembali dalam Kriminologi dan Sistem Peradilan Pidana, Kumpulan karangan Buku Kedua 140, (Pusat Pelayanan Keadilan dan Pengabdian Hukum, Universitas Indonesia, Jakarta, 1994).

11 Id.

12 Eva Achjani Zulfa, supra catatan no. 9.

13 Eva Achjani Zulfa, supra catatan no. 6. 
Pendekatan keadilan restoratif merupakan sebuah paradigma baru dalam merespon terjadinya tindak pidana. Dalam perspektif pendekatan keadilan restoratif, tindak pidana dipahami sebagai suatu sengketa atau konflik yang merusak hubungan antar individu dan masyarakat (bukan sekedar sebagai pelanggaran hukum dimana sebagai konsekuensinya pelakunya akan berhadapan dengan negara). ${ }^{14}$ Dengan kata lain, korban atas terjadinya tindak pidana bukanlah negara, melainkan individu. Oleh karenanya kejahatan menciptakan kewajiban untuk membenahi rusaknya hubungan akibat terjadinya suatu tindak pidana. ${ }^{15}$

Para pihak yang dianggap terkena dampak dari tindak pidana tersebut secara langsung adalah korban, masyarakat dan pelaku, sehingga keadilan baru dapat terwujud apabila pihak-pihak terkait tersebut diberi ruang untuk berpartisipasi secara aktif dalam proses penyelesaian perkara ${ }^{16}$ dalam rangka mencari solusi terbaik yang mengutamakan pemulihan, rekonsiliasi dan saling memaafkan. ${ }^{17}$ Konsekuensi dari penerapan pendekatan keadilan restoratif ini adalah keadilan tidak lagi difokuskan pada persoalan pemidanaan (menghukum) pelaku karena pemulihan kerugian yang timbul sebagai akibat dari suatu tindak pidana menjadi sesuatu yang jauh lebih penting. ${ }^{18}$

Pendekatan ini berbasis pada upaya untuk menyeimbangkan fokus antara korban, pelaku dan masyarakat yang terkena dampak tindak pidana ${ }^{19}$ dengan tujuan utama menciptakan kedamaian dalam masyarakat dengan cara memulihkan hubungan antara para pihak (pelaku dan korban) serta memperbaiki

\footnotetext{
${ }^{14}$ Mark Umbreit, Restorative Juvenile Justice: Repairing the Harm of Youth Crime edited by Gordon Bazemore and Lode Walgrave 213 (Criminal Justice Press, New York, 1999).

15 John Braithwaite and Heather Strang, Restorative Justice and Civil Society 166 (2001).

16 Mark Umbreit, supra catatan no. 14.

17 Howard Zehr, Changing Lenses : A New Focus for Crime and Justice 181 (Herald Press, Scottdale, PA, 1990).

18 Mark Umbreit, supra catatan no. 15.

19 George Ritzer dalam Sosiologi : Ilmu Pengetahuan Berparadigma Ganda (PT. Raja Grafindo Persada, Jakarta, 2004).
} 
berbagai kerusakan sebagai akibat dari suatu tindak pidana yang dianggap sebagai suatu sengketa atau konflik dalam hubungan kemasyarakatan. ${ }^{20}$

Jika dibandingkan, memang terdapat perbedaan cara pandang dalam memahami tindak pidana dan keadilan dalam sistem peradilan pidana dan pendekatan keadilan restoratif. Perbedaan antara keduanya dapat digambarkan sebagai berikut :

\begin{tabular}{|c|c|c|}
\hline Indikator & Sistem Peradilan Pidana & Pendekatan Keadilan Restoratif \\
\hline $\begin{array}{l}\text { Pemahaman terhadap } \\
\text { tindak pidana }\end{array}$ & $\begin{array}{l}\text { Tindak Pidana dipahami sebagai } \\
\text { serangan terhadap negara } \rightarrow \\
\text { konsekuensi logis dari } \\
\text { pemahaman terhadap konsep } \\
\text { ius poenale dan ius puniendi. }\end{array}$ & $\begin{array}{l}\text { Tindak Pidana dipahami sebagai } \\
\text { serangan terhadap individu dan } \\
\text { hubungan kemasyarakatan } \rightarrow \\
\text { konsekuensi dari pemikiran } \\
\text { bahwa Tindak Pidana pada } \\
\text { prinsipnya menyebabkan } \\
\text { rusaknya hubungan antar individu } \\
\text { dalam masyarakat. }\end{array}$ \\
\hline $\begin{array}{l}\text { Pemahaman terhadap } \\
\text { keadilan }\end{array}$ & $\begin{array}{l}\text { Keadilan dianggap terwujud } \\
\text { dengan mengacu pada jumlah } \\
\text { perkara yang diproses dan } \\
\text { pidana yang dijatuhkan } \\
\text { terhadap pelaku. }\end{array}$ & $\begin{array}{l}\text { Keadilan dianggap terwujud } \\
\text { dalam hal : } \\
\text { - } \text { Ditemukannya solusi terbaik } \\
\text { baik bagi pelaku, korban } \\
\text { maupun masyarakat untuk } \\
\text { menyelesaikan sengketa atau } \\
\text { konflik yang terjadi (win win } \\
\text { solution) sehingga hubungan } \\
\text { kemasyarakatan yang sempat } \\
\text { rusak dapat dipulihkan } \\
\text { kembali. } \\
\text { - Kesepakatan para pihak } \\
\text { tersebut dapat sungguh- } \\
\text { sungguh dijalankan. }\end{array}$ \\
\hline
\end{tabular}

\section{Upaya Melibatkan Partisipasi Korban dan Pelaku Secara Langsung Dalam} Penerapan Pendekatan Keadilan Restoratif

Selain terjadi pergeseran pemikiran dalam memahami apa yang dimaksud dengan tindak pidana dan bagaimana keadilan harus dipahami, salah satu indikator penting yang membedakan sistem peradilan pidana dan pendekatan keadilan restoratif adalah persoalan partisipasi korban dan pelaku. Persoalan partisipasi ini menjadi sama pentingnya karena pada dasarnya keadilan restoratif yang menjadi tujuan akhir baru dapat terwujud apabila korban dan pelaku terlibat

20 Burt Galaway and Joe Hudson, Criminal Justice, Restitution and Reconciliation (Criminal Justice Press, New York, 1990). 
secara langsung (berpartisipasi secara aktif) dalam upaya menentukan solusi terbaik bagi semua pihak.

Tulisan ini lebih difokuskan pada bagaimana hukum acara pidana dapat mewadahi partisipasi korban dan pelaku secara langsung dalam penyelesaian perkara pidana. Dengan kata lain, terminologi "pendekatan keadilan restoratif" yang dimaksud dalam tulisan ini memang lebih dititikberatkan pada kesepakatan perdamaian antara pelaku dan korban dan bagaimana kemudian hukum acara mengakui keberadaan kesepakatan perdamaian tersebut sebagai kesepakatan yang memiliki kekuatan hukum. Namun demikian apa yang sangat perlu mendapatkan perhatian adalah jangan sampai penerapan pendekatan keadilan restoratif ini disimplifikasi dan diartikan secara dangkal sebatas sebuah kesepakatan perdamaian karena jika demikian proses yang berjalan justru akan terjebak pada sebatas menjalankan fungsi prosedural saja sehingga kebenaran (khususnya kebenaran materil) dan keadilan tidak dapat tercapai. ${ }^{21}$

Sebagaimana telah dikemukakan sebelumnya, karakteristik hukum pidana sebagai hukum publik yang tampak dari dominasi peran negara melalui alat-alat kekuasannya dalam sistem peradilan pidana berimplikasi pada tidak diakuinya keberadaan korban dan pelaku sebagai pihak yang menentukan dalam penyelesaian suatu perkara pidana. Dalam sistem peradilan pidana, pemenuhan rasa keadilan korban sangat tergantung pada empati Jaksa Penuntut Umum. Keterangan saksi korban yang merupakan salah satu alat bukti diminta guna mendukung atau dengan kata lain memberikan pembenaran atas dakwaan dan tuntutan jaksa. Selain itu, pemidanaan terhadap pelaku juga dibatasi oleh jenisjenis sanksi yang ditentukan secara tegas oleh peraturan perundang-undangan yang sebenarnya tidak menawarkan keuntungan apapun kepada korban karena

21 Pendapat ini disampaikan oleh Agustinus Pohan (pengajar Kriminologi, Hukum Pidana dan Hukum Acara Pidana) dan Suadamara Ananda (pengajar Filsafat Hukum) dalam presentasi makalah berjudul "Pendekatan Keadilan Restoratif: Upaya Melibatkan Partisipasi Korban dan Pelaku Secara Langsung dalam Penyelesaian Perkara Pidana”, oleh Penulis dihadapan seluruh dosen tetap Fakultas Hukum Universitas Katolik Parahyangan dalam diskusi rutin yang diadakan oleh Laboratorium Hukum Fakultas Hukum Universitas Katolik Parahyangan, Bandung 15 Desember 2014. 
memang sanksi-sanksi pidana tersebut ditujukan sebagai alat pemberian derita bagi pelaku. ${ }^{22}$ Selain korban, pelakupun ternyata berada dalam keadaan yang tidak cukup menguntungkan karena pada dasarnya, sistem peradilan pidana lebih difokuskan pada pembuktikan kesalahan pelaku, bukan pemulihan kondisi seperti semula sebelum terjadinya tindak pidana. Bentuk pertanggungjawaban pelaku (sanksi pidana) yang dijatuhkan juga sangat dibatasi oleh undang-undang sehingga pelaku tidak dapat mewujudkan bentuk pertanggungjawaban lain yang tidak diatur dalam undang-undang. ${ }^{23}$ Beberapa undang-undang yang mengatur ketentuan mengenai pemberian restitusi dan kompensasi bagi korban pada prinsipnya dapat menjadi instrumen pendukung penerapan pendekatan keadilan restoratif. ${ }^{24}$ Namun demikian, penerapan pendekatan keadilan restoratif ini masih sangat terbatas sifatnya karena ruang bagi korban dan pelaku untuk menentukan bentuk pertanggungjawaban yang diinginkan belum mendapatkan tempat. ${ }^{25}$

Persoalan aspirasi korban yang tidak cukup terwakili dengan baik dalam sistem peradilan pidana serta penyelesaian perkara pidana yang dianggap tidak memberikan keuntungan yang dapat dirasakan secara langsung baik oleh korban maupun pelaku menjadi sejumlah permasalahan dalam sistem peradilan pidana. ${ }^{26}$

22 Eva Achjani Zulfa, supra catatan no. 9.

Lihat juga Rudi Satriyo, Pelaksanaan Advokasi Terhadap Kekerasan Dalam Rumah Tangga Dalam Perspektif Hukum dan Hak Asasi Manusia (Balitbang HAM-Departemen Hukum dan HAM RI, 2006). Tim Peneliti Balitbang HAM Departemen Hukum dan HAM RI pada tahun 2006 menemukan bahwa untuk penyelesaian perkara kejahatan yang terkait dengan harta kekayaan, bagi korban yang terpenting adalah pengembalian barang atau pembayaran ganti kerugian yang timbul, bukan pada masalah pemidanaannya.

23 Id. Sebagai contoh, dalam perkara kecelakaan lalu lintas, keluarga korban bisa jadi lebih memilih untuk menerima uang santunan dari pelaku yang dapat digunakan sebagai modal usaha. Atau dapat juga terjadi bahwa mengingat proses pidana atas suatu perkara akan memakan biaya tidak sedikit, dengan mempertimbangkan kondisi ekonomi pelaku dan korban yang kurang baik dan juga karena keluarga korban pun telah memaafkan pelaku, polisi memutuskan untuk tidak melanjutkan proses hukum atas perkara tersebut.

${ }^{24}$ Saat ini sudah terdapat beberapa undang-undang yang pada prinsipnya mendukung penerapan pendekatan keadilan restoratif, diantaranya ketentuan mengenai pemberian ganti rugi melalui mekanisme pra peradilan dalam KUHAP dan ketentuan mengenai pemberian restitusi dan kompensasi bagi korban dalam Undang-Undang No. 20 Tahun 2006 Tentang Pengadilan Hak Asasi Manusia dan Undang-Undang No. 13 Tahun 2006 Tentang Perlindungan Saksi dan Korban.

25 Eva Achjani Zulfa, supra catatan no. 6.

26 Id. 
Pendekatan keadilan restoratif hadir sebagai respon terhadap berbagai persoalan tersebut dengan mencoba melibatkan korban yang merasa tersisih dengan mekanisme yang bekerja pada sistem peradilan pidana yang ada saat ini. Selain itu, pendekatan keadilan restoratif juga merupakaan suatu kerangka berpikir yang baru yang dapat digunakan penegak hukum dalam merespon terjadinya tindak pidana. ${ }^{27}$ Beberapa hal yang kemudian harus diperhatikan terkait operasionalisasi pendekatan keadilan restoratif dalam mengupayakan partisipasi korban dan pelaku secara langsung ini adalah penerapan pendekatan ini harus dilakukan secara sukarela dengan didasarkan pada persetujuan bebas para pihak ${ }^{28}$ dan dapat dilakukan dalam setiap tahap dalam proses peradilan pidana. ${ }^{29}$

Terkait pilihan untuk menerapkan pendekatan keadilan restoratif yang harus dilakukan secara sukarela, perdamaian sesungguhnya menjadi pintu masuk untuk dapat diterapkannya pendekatan ini. Selalu terdapat kemungkinan bahwa para pihak yang terlibat dalam suatu konflik atau sengketa dalam hal terjadinya tindak pidana memilih untuk melakukan perdamaian dan tidak melanjutkan proses hukum atas perkara tersebut. Perdamaian dapat dilakukan para pihak dengan melibatkan baik subsistem yang terdapat didalam maupun diluar sistem peradilan pidana.

Eva Achjani Zulfa dalam disertasinya yang berjudul "Keadilan Restoratif di Indonesia (Studi Tentang Kemungkinan Penerapan Pendekatan Keadilan Restoratif Dalam Praktek Penegakan Hukum Pidana)" menyatakan bahwa secara

27 Id. Selain itu Bagir Manan berpendapat bahwa hambatan dalam melaksanakan perdamaian antara korban dan pelaku seringkali bersumber pada sikap penegak hukum yang sangat formalistik dengan mengatakan proses hukum akan tetap berjalan walaupun telah terjadi perdamaian. Lihat juga Jecky Tengens, Pendekatan Restorative Justice dalam Sistem Peradilan Pidana Indonesia, http://www.hukumonline.com/berita/baca/ lt4e25360a422c2pendekatan28 Id.

29 Perserikatan Bangsa-Bangsa (PBB) telah menggunakan keadilan restoratif sebagai pedoman dalam penanganan kejahatan melalui Basic principles on the use of restorative justice programmes in criminal matters. Pasal II.6 Economic and Social Council (ECOSOC Resolution) United Nations 2002/12 Basic principles on the use of restorative justice programmes in criminal matters menyatakan "Restorative justice programmes may be used at any stage of the criminal justice system, subject to national law." 
teoritis terdapat 3 (tiga) model yang menempatkan hubungan keadilan restoratif dengan sistem peradilan pidana, yaitu : ${ }^{30}$

1. Sebagai bagian dari sistem peradilan pidana $\rightarrow$ resolusi dua arah $\rightarrow$ sistem peradilan pidana dan pendekatan keadilan restoratif berjalan secara beriringan $\rightarrow$ hakim menjadikan perdamaian yang telah disepakati korban dan pelaku sebagai dasar peringan atau penghapus pidana.

2. Diluar sistem peradilan pidana melalui lembaga atau institusi lain diluar sistem $\rightarrow$ perdamaian sebagai dasar penghapus penuntutan $\rightarrow$ hakim membuat penetapan untuk tidak dilanjutkannya penuntutan atas perkara pidana yang berujung dengan perdamaian. 31

3. Diluar sistem peradilan pidana dengan tetap melibatkan pihak penegak hukum $\rightarrow$ perluasan diskresi atau oportunitas $\rightarrow$ polisi dan jaksa mengalihkan proses hukum atas suatu perkara pidana keluar sistem peradilan pidana (diversi) untuk ditangani lembaga atau institusi lain diluar sistem $\rightarrow$ perdamaian dicatatkan dalam administrasi kepolisian atau kejaksaan.

Yang perlu menjadi catatan dalah bahwa dalam penerapan pendekatan keadilan restoratif ini lembaga atau institusi lain diluar sistem memegang peranan penting. Lembaga atau institusi lain diluar sistem yang dimaksud dalam hal ini antara lain adalah masyarakat yang diwakili oleh perangkat pemerintahan desa dan pengadilan adat. ${ }^{32}$ Peran masyarakat dan lembaga adat menjadi penting karena subsistem diluar sistem peradilan pidana inilah yang pada akhirnya akan berusaha mendamaikan pelaku dan korban. Subsistem didalam sistem peradilan

30 Eva Achjani Zulfa, supra catatan no. 5, pada 33, 72-75.

Lihat juga Nathalina Naibaho, Perkembangan Teori-Teori Hukum Pidana, Restorative Justice, Pascasarjana Fakultas Hukum Universitas Indonesia, 2010.

Jolien Willemsens, Repotioning Restorative Justice, 24 (Willam Publishing, Devon, 2003).

"Restorative justice should function as part of (or as alternative to) the criminal justice system."

31 Eva Achjani Zulfa, supra catatan no. 9.

Selain hakim yang berperan membuat penetapan untuk tidak dilanjutkannya penuntutan atas perkara pidana yang berujung dengan perdamaian, dalam hal alternatif mekanisme ini diterapkan, polisi juga berperan penting dalam bertindak sebagai mediator untuk mendamaikan pelaku dan korban melalui mekanisme mediasi penal.

32 Eva Achjani Zulfa, supra catatan no. 6, pada 63. 
pidana (polisi dan jaksa) hanya sebatas melakukan diversi. Apabila perdamaian berhasil dicapai, hal tersebut akan dicatatkan sebagai alasan penghentian penyidikan atau penuntutan. Sementara itu, hakim juga hanya akan membantu mencatatkan perdamaian tersebut sebagai dasar agar atas perkara tersebut proses hukumnya secara otomatis dihentikan.

\section{Persoalan Pengaturan Kewenangan Subsistem Didalam dan Diluar Sistem Peradilan Pidana Terkait Penerapan Pendekatan Keadilan Restoratif}

Berbicara dalam konteks penerapan pendekatan keadilan restoratif, terdapat subsistem-subsistem yang akan terlibat didalamnya, baik subsistem yang berada didalam maupun diluar sistem peradilan pidana. Persoalan mendasar yang kemudian muncul adalah undang-undang tidak mengatur mengenai kekuatan hukum atas kesepakatan perdamaian antara pelaku dan korban dan kewenangan masing-masing subsistem tersebut untuk menerapkan pendekatan keadilan restoratif dalam hal terjadinya tindak pidana (termasuk didalamnya mencatatkan perdamaian sebagai alasan penghentian proses hukum atas perkara tersebut). Tulisan ini hanya akan spesifik membahas mengenai kelemahan mendasar dalam undang-undang yang tidak mengatur secara jelas kewenangan subsistem dalam sistem peradilan pidana saja (polisi, jaksa dan hakim) untuk menerapkan pendekatan keadilan restoratif.

1. Kewenangan polisi

Apabila ditelusuri, persoalan yang timbul dalam hal penerapan pendekatan keadilan restoratif pada tahap pra adjudikasi yang dalam hal ini melibatkan subsistem kepolisian sesungguhnya berakar dari definisi yang tidak memadai yang diberikan undang-undang mengenai apa yang dimaksud dengan penghentian penyidikan dan diskresi. Definisi penghentian penyidikan dan diskresi tersebut menjadi sangat penting karena pada prinsipnya kedua lembaga tersebut merupakan instrumen pendukung penerapan pendekatan keadilan restoratif yang dalam hal ini jika dikaitkan dengan bagian 
sebelumnya dari tulisan ini, polisi harus memiliki kewenangan baik untuk mengalihkan perkara keluar sistem peradilan pidana untuk ditangani subsistem lain diluar sistem peradilan pidana melalui mekanisme diversi atau bertindak sebagai mediator untuk mendamaikan pelaku dan korban melalui mekanisme mediasi penal. Baik diversi maupun mediasi penal ini terkait erat dengan kewenangan diskresi dan penghentian penyidikan oleh polisi.

a. Alasan penghentian penyidikan

Ketentuan Pasal 109 ayat 2 Kitab Undang Undang Hukum Acara Pidana (KUHAP) menyebutkan hal-hal yang dapat digunakan sebagai alasan untuk menghentikan penyidikan adalah tidak terdapat cukup bukti, peristiwa tersebut ternyata bukan merupakan tindak pidana atau penyidikan dihentikan demi hukum. ${ }^{33}$ Alasan penghentian penyidikan demi hukum ini pada prisipnya sejalan dengan alasan penghentian penuntutan yang diatur secara limitatif dalam Kitab Undang Undang Hukum Pidana (KUHP), yaitu ne bis in idem (Pasal 76 KUHP), terdakwa meninggal dunia (Pasal 77 KUHP), daluwarsa penuntutan pidana (Pasal 78 KUHP), tidak adanya pengaduan dalam delik aduan (Pasal 72 KUHP) dan affdoening buiten procces, yaitu batalnya hak untuk melakukan penuntutan karena adanya pembayaran denda yang setinggi-tingginya secara sukarela pada pelanggaran-pelanggaran (Pasal 82 KUHP).

b. Diskresi kepolisian

Ketentuan Pasal 18 ayat 1 Undang Undang No. 2 Tahun 2002 Tentang Kepolisian yang mengatur mengenai diskresi ${ }^{34}$ diterjemahkan sebagai kewenangan yang dilaksanakan bilamana seorang petugas Kepolisian Negara Republik Indonesia yang bertugas seorang diri ditengah-tengah masyarakat harus mampu mengambil keputusan berdasarkan penilaiannya sendiri apabila terjadi gangguan terhadap ketertiban dan dan keamanan

33 Undang Undang R.I. No. 8 Tahun 1981, Hukum Acara Pidana, L.N.R.I Tahun 1981 No. 76, Pasal 109 ayat (2).

34 Undang Undang R.I., No. 2 Tahun 2002, Kepolisian, L.N.R.I Tahun 2002 No. 2, Pasal 18 ayat (1). 
umum atau apabila diperkirakan akan timbul bahaya bagi ketertiban dan keamanan umum, dimana dalam keadaan seperti itu tidak mungkin baginya untuk meminta petunjuk atau pengarahan terlebih dahulu dari atasannya. ${ }^{35}$

Apabila mengacu pada kedua definisi tersebut, praktis polisi tidak memiliki dasar yang kuat apabila hendak melakukan penghentian penyidikan atas suatu perkara baik atas dasar diskresi maupun kewenangan menghentikan penyidikan. Ruang untuk melakukan diversi maupun mediasi penal juga tidak diatur undang-undang. Dengan demikian tidaklah salah jika sebagian besar anggota kepolisian memandang bahwa setiap perkara yang ditanganinya harus dilanjutkan prosesnya ke tahap penuntutan kecuali dalam hal-hal yang memang diatur menurut hukum. ${ }^{36}$

\section{Kewenangan jaksa}

Persoalan serupa juga dijumpai dalam definisi terkait lembaga penghentian penuntutan dan oportunitas jaksa yang diberikan undang-undang.

a. Alasan penghentian penuntutan

Ketentuan Pasal 140 ayat 2 KUHAP menyebutkan hal-hal yang dapat digunakan sebagai alasan untuk menghentikan penuntutan adalah tidak terdapat cukup bukti, peristiwa tersebut ternyata bukan merupakan tindak

35 Buku Pedoman Pelaksanaan Tugas Bintara Polisi di lapangan (SK Kalemdiklat Polri No. Pol: SKEP/65/III/2003 tanggal 24 Maret 2003) hal. 132 dalam supra catatan no. 7.

36 Dalam penelitian disertasinya, Eva Achjani Zulfa menyatakan bahwa, dalam praktek di lapangan polisi ternyata telah mencoba menerapkan pendekatan keadilan restoratif meskipun belum memiliki payung hukum. Hal itu dilakukan dengan mengambil kebijaksanaan untuk tidak melanjutkan proses suatu perkara pidana semata-mata dengan pertimbangan kemanusiaan seperti jenis tindak pidana yang dianggap ringan dengan pertimbangan ancaman pidana dibawah lima tahun dan kesalahan berupa kelalaian, kondisi ekonomi kedua belah pihak (pelaku dan korban) mengingat untuk melanjutkan perkara ke tahap-tahap berikutnya memerlukan dana yang tidak sedikit. Pilihan untuk melanjutkan atau tidak melanjutkan perkara ini selalu ditanyakan polisi kepada korban atau keluarga korban terlebih dahulu. Mekanisme penyelesaian seperti ini belum diatur dan tidak dikenal dalam aturan perundangundangan maupun dalam administrasi kepolisian. Dalam kenyataannya, perkara-perkara yang diselesaikan melalui mekanisme ini cenderung tidak dicatatkan atau kalaupun dicatatkan cenderung direduksi kedalam alasan-alasan yang ada dalam KUHP maupun KUHAP. hlm 5 
pidana atau perkara ditutup demi hukum. ${ }^{37}$ Perkara ditutup demi hukum sebagai alasan penghentian penuntutan pada prinsipnya didasarkan pada alasan ne bis in idem (Pasal 76 KUHP), terdakwa meninggal dunia (Pasal 77 KUHP), daluwarsa penuntutan pidana (Pasal 78 KUHP), tidak adanya pengaduan dalam delik aduan (Pasal 72 KUHP) dan affdoening buiten procces (Pasal 82 KUHP).

b. Oportunitas jaksa

Sementara itu, terkait asas oportunitas, ketentuan Pasal 32 huruf c Undang Undang No. 16 Tahun 2004 Tentang Kejaksaan Republik Indonesia menyatakan bahwa kewenangan untuk menyampingkan perkara demi kepentingan umum (mendeponir perkara) hanya dimiliki oleh Jaksa Agung dan tidak dimiliki oleh setiap Penuntut Umum yang tengah menangani perkara pidana. ${ }^{38}$ Konsekuensinya, Penuntut Umum yang menangani suatu perkara tidak memiliki kewenangan untuk mengenyampingkan (mendeponir) perkara karena harus terlebih dahulu melaporkannya kepada atasannya untuk dimintakan persetujuan dari Jaksa Agung.

Kembali mengacu pada salah satu alternatif mekanisme penerapan pendekatan keadilan restoratif melalui diversi yang dilakukan jaksa, aturan hukum saat ini yang mengatur mengenai kewenangan jaksa untuk menghentikan penuntutan atau mendeponir suatu perkara tampak belum mendukung penerapan diversi tersebut.

Mengingat mainstream berpikir dari petugas penegak hukum yang sudah terpola dengan alur berpikir konvensional sistem peradilan pidana $^{39}$, berbagai persoalan tersebut berimplikasi pada persoalan tidak dapat dihentikannya penyidikan atau penuntutan atas suatu perkara pidana karena memang persyaratan yang ditentukan undang-undang secara limitatif untuk dapat dihentikannya penyidikan atau penuntutan

37 Supra catatan no. 33.

38 Undang Undang R.I., No. 16 Tahun 2004, Kejaksaan, L.N.R.I. Tahun Tahun 2004 No. 67, Pasal 32 huruf c.

39 Eva Achjani Zulfa, supra catatan no. 5, pada 5. 
suatu perkara tidak terpenuhi. Akibatnya, penerapan pendekatan keadilan restoratif baik melalui mekanisme diversi maupun mediasi penal juga menjadi terhambat karena perkara yang bersangkutan harus tetap diteruskan pemeriksaannya sesuai ketentuan undang-undang.

3. Kewenangan hakim

Sementara itu, ruang bagi hakim untuk menerapkan pendekatan keadilan restoratif ini secara implisit tertuang dalam ketentuan Pasal 5 ayat 1 UndangUndang-Undang Nomor 48 Tahun 2009 tentang Ketentuan-Ketentuan Pokok Kekuasaan Kehakiman yang pada intinya menyatakan bahwa hakim wajib menggali rasa keadilan yang hidup dalam masyarakat. Rasa keadilan yang hidup dalam masyarakat ini kemudian menjadi relevan ketika dikaitkan dengan tindak pidana yang berujung dengan perdamaian antara pelaku dan korban yang diterima para pihak sebagai apa yang bagi mereka adalah adil. ${ }^{40}$ Namun demikian, kemungkinan penerapan pendekatan keadilan restoratif oleh hakim tersebut belum didukung dasar hukum yang secara eksplisit menyatakan bahwa hakim memiiliki kewenangan untuk menjadikan perdamaian yang telah disepakati korban dan pelaku sebagai dasar peringan atau penghapus pidana atau membuat penetapan untuk tidak dilanjutkannya penuntutan atas perkara pidana yang berujung dengan perdamaian. ${ }^{41}$

Selain melibatkan subsistem dalam sistem peradilan pidana, penerapan pendekatan keadilan restoratif ini juga melibatkan subsistem diluar sistem peradilan pidana, baik masyarakat, pengadilan adat atau lembaga lain yang dalam hal ini kewenangannya juga harus secara tegas diatur oleh undangundang sehingga kesepakatan perdamaian antara pelaku dan korban yang

\footnotetext{
40 Undang Undang R.I., No. 48 Tahun 2009, Kekuasaan Kehakiman, L.N.R.I Tahun 2009 No. 157, Pasal 5 ayat (1).

${ }^{41}$ Berbeda dengan perkara perdata, pasal 4 Peraturan Mahkamah Agung Republik Indonesia No. 1 Tahun 2008 Tentang Prosedur Mediasi di Pengadilan menyatakan bahwa semua sengketa perdata yang diajukan ke Pengadilan Tingkat Pertama wajib lebih dahulu diupayakan penyelesaian melalui perdamaian dengan bantuan mediator.
} 
difasilitasi subsistem diluar sistem peradilan pidana tersebut tidak dipersoalkan keabsahan atau kekuatan hukumnya.

\section{Kualifikasi Tindak Pidana yang Dapat Diselesaikan Dengan Pendekatan Keadilan Restoratif}

Sebagai hukum publik yang mengutamakan kepentingan umum, penerapan hukum pidana melalui alat-alat kekuasaan negara mendapatkan legitimasinya. Dalam hal ini, bukanlah orang-perorangan yang akan bertindak jika terjadi pelanggaran hukum, tetapi negara melalui alat-alatnya. Diutamakannya kepentingan umum (masyarakat) dapat terlihat melalui penjatuhan sanksi pidana yang didahulukan jika dibandingkan dengan pemberian ganti rugi atas dilanggarnya kepentingan pribadi korban. ${ }^{42}$ Dengan mengancam pidana tingkah laku manusia, berarti negara mengambil alih tanggung jawab mempertahankan peraturan-peraturan yang telah ditentukan yang tidak lagi diserahkan kepada orang-perorangan. Negara dalam hal ini memikul tugas menyidik dan menuntut pelanggaran peraturan yang berisi ancaman pidana. ${ }^{43}$ Dalam konteks ini, negara justru hadir untuk mencegah terjadinya tindakan "main hakim sendiri". Namun demikian, saat ini pemikiran tersebut justru dihadapkan pada realita kebutuhan masyarakat atas mekanisme penyelesaian perkara pidana yang dianggap lebih mengakomodasi partisipasi dan aspirasi korban dan pelaku. ${ }^{44}$ Pendekatan keadilan restoratif hadir sebagai alternatif mekanisme penyelesaian perkara pidana yang diharapkan dapat menutupi salah satu kekurangan dalam sistem peradilan pidana tersebut.

${ }^{42}$ Andi Hamzah, Asas Asas Hukum Pidana 5, (Rineka Cipta, Jakarta, 2003).

43 Id.

44 Rudi Satriyo, Pelaksanaan Advokasi Terhadap Kekerasan Dalam Rumah Tangga Dalam Perspektif Hukum dan Hak Asasi Manusia, (Balitbang HAM - Departemen Hukum dan HAM RI, 2006). Tim Peneliti Balitbang HAM Departemen Hukum dan HAM RI pada tahun 2006 menemukan bahwa dalam kebanyakan kasus kekerasan dalam rumah tangga justru polisi bertindak sebagai mediator. Hal ini disebabkan suami atau istri korban justru memohon kepada penyidik agar perkaranya tidak dilanjutkan ke proses selanjutnya karena ingin mempertahankan rumah tangganya. Sementara itu, untuk penyelesaian perkara kejahatan yang terkait dengan harta kekayaan, bagi korban yang terpenting adalah pengembalian barang atau pembayaran ganti kerugian yang timbul, bukan pada masalah pemidanaannya. 
Profesor Sudarto menyatakan bahwa fungsi khusus hukum pidana ialah melindungi kepentingan hukum terhadap perbuatan yang hendak memperkosanya dengan sanksi yang berupa pidana yang sifatnya lebih tajam jika dibandingkan dengan sanksi yang terdapat pada cabang hukum lainnya. Kepentingan-kepentingan hukum ini dapat berupa kepentingan hukum individu (yang dapat berupa kepentingan hukum atas hak hidup (nyawa), tubuh, hak milik benda, harga diri atau nama baik dan kesusilaan), kepentingan hukum masyarakat maupun kepentingan hukum negara. ${ }^{45}$ Terkait fungsi khusus hukum pidana tersebut, apa yang perlu diperhatikan adalah bahwa tidak semua tindak pidana dapat diselesaikan dengan menggunakan pendekatan keadilan restoratif karena selain pendekatan keadilan restoratif ini baru bisa diterapkan apabila ada persetujuan bebas para pihak, pada prinsipnya kekhasan hukum pidana jika dibandingkan dengan hukum-hukum lain justru terletak pada penderitaan yang bersifat khusus berupa pembatasan dan perampasan kemerdekaan ${ }^{46}$ yang tertuang dalam sanksi pidana atas kepentingan hukum yang "diperkosa” tersebut. Singkat kata, mengingat besarnya kepentingan untuk melindungi kepentingan hukum tersebut, perlindungan tersebut harus dilakukan dengan menggunakan sanksi pidana yang bersifat khusus jika dibandingkan dengan instrumen hukum lain.

Model pendekatan keadilan restoratif ini banyak digunakan untuk tindak pidana yang dilakukan oleh anak-anak dan remaja atau tindak pidana yang berkaitan dengan penduduk asli tertentu (indigineous offenders). ${ }^{47}$ Sementara itu, Eva Achjani Zulfa berpendapat bahwa pada dasarnya penerapan pendekatan keadilan restoratif ini sangat mungkin diterapkan dalam berbagai jenis tindak pidana yang sifatnya umum dan bukan merupakan perbuatan yang pelaku dan korbannya tidak dapat teridentifikasi secara jelas, bersifat politis dan mengancam

45 Sudarto, supra catatan no. 2, pada 12.

46 P.A.F Lamintang, supra catatan no. 8, pada 16.

47 Sir Anthony Mason dalam Heather Strang and John Braithwaite, Restorative Justice: Philosophy to Practice 1 (Ashage Publishing Company, Burlington, 2000). 
keselamatan masyarakat secara luas. ${ }^{48}$ Selain itu, patut pula diperhatikan bahwa penanganan tindak pidana yang mengancam hak hidup (nyawa) dan tubuh serta kehormatan kesusilaan, perlu dipertimbangkan perlu tidaknya penerapan pendekatan keadilan restoratif mengingat karakteristik kasus dan sifat berbahayanya tindak pidana terhadap masyarakat. Sementara terhadap tindak pidana yang mengancam harga diri (nama baik) dan hak milik (harta benda), sifat privat dari jenis tindak pidana ini menjadikan penanganan tindak pidana dengan menggunakan keadilan restoratif secara murni dapat diterapkan. Kerugian yang mengacu pada kepentingan orang-perorangan memungkinkan model penyelesaian melalui jalur musyawarah dan mediasi menjadi lebih terbuka. ${ }^{49}$

Spesifik berbicara mengenai kewenangan Penuntut Umum untuk menghentikan penuntutan, Pasal 42 ayat (2), (3) dan (4) Rancangan Kitab Undang-Undang Hukum Acara Pidana (RKUHAP) tahun 2014 ternyata telah memberikan ruang bagi Penuntut Umum untuk menghentikan penuntutan dengan alasan :

1. tindak pidana yang dilakukan bersifat ringan;

2. tindak pidana yang dilakukan diancam dengan pidana penjara paling lama 4 (empat) tahun;

3. tindak pidana yang dilakukan hanya diancam dengan pidana denda;

4. umur tersangka pada waktu melakukan tindak pidana di atas 70 (tujuh puluh) tahun ; dan/atau

5. kerugian sudah diganti.

48 Dalam disertasinya Eva Achjani Zulfa melakukan penelitian terhadap beberapa putusan pengadilan yang ternyata menunjukkan bahwa hakim menjadikan perdamaian sebagai dasar peringan atau penghapus pidana. Namun demikian, dalam kasus dimana tindak pidana yang dilakukan dianggap bersifat berbahaya dan mengancam serta meresahkan masyarakat luas, perdamaian antara pelaku dan korban tidak diperhitungkan sebagai baik alasan peringan maupun penghapus pidana. Sebagai contoh, Putusan Mahkamah Agung No. 2127 K/Pid/2001 dalam kasus kelalaian yang menyebabkan orang lain luka (perkara lalu lintas), mempertimbangkan perdamaian sebagai alasan penghapus pidana ; namun Putusan Mahkamah Agung No. 15 K/Pid/2007 dalam kasus eksploitasi seksual terhadap anak dibawah umur 15 tahun tidak mempertimbangkan "perdamaian" melalui upaya pelaku menikahi korban sebagai alasan peringan atau penghapus pidana sehingga pelaku tetap dipidana.

49 Eva Achjani Zulfa, supra catatan no. 6, pada 68-69. 
Untuk dua kategori terakhir (nomor 4 dan 5) undang-undang mensyaratkan bahwa ketentuan tersebut hanya berlaku untuk tindak pidana yang diancam dengan pidana penjara paling lama 5 (lima) tahun..$^{50}$

Kewenangan Penuntut Umum ini juga didukung oleh kewenangan Hakim Pemeriksa Pendahuluan untuk memutus layak tidaknya suatu perkara dilanjutkan ke tahap penuntutan atas permintaan Penuntut Umum yang diatur dalam ketentuan Pasal 44 ayat (1) dan (2) RKUHAP tahun 2014.51 Pasal 153 huruf d Rancangan Kitab Undang Undang Hukum Pidana (RKUHP) tahun 2015 juga mengatur bahwa salah satu alasan yang menyebabkan gugurnya kewenangan penuntutan adalah penyelesaian perkara diluar proses. ${ }^{52}$

Sebagaimana telah dipaparkan pada bagian sebelumnya dalam tulisan ini, salah satu persoalan mendasar apabila pendekatan keadilan restoratif ini hendak diterapkan adalah persoalan kewenangan baik polisi, jaksa maupun hakim untuk menerapkan pendekatan keadilan restoratif yang belum secara tegas diatur oleh undang-undang. Dengan mengacu pada ketentuan pasal-pasal dalam RKUHP dan RKUHAP diatas terlihat bahwa terbuka ruang untuk dihentikannya penuntutan terhadap perkara tertentu yang secara limitatif diatur dalam undang-undang. Kewenangan ini diberikan oleh undang-undang kepada jaksa yang juga didukung dengan kewenangan Hakim Pemeriksa Pendahuluan. Selain itu, undang-undang juga telah secara eksplisit menyatakan bahwa penyelesaian perkara diluar sistem peradilan pidana menjadi salah satu alasan penghentian penuntutan. Pengaturan demikian memperlihatkan bahwa terdapat perubahan pengaturan dalam Rancangan terkait alasan penghapus penuntutan yang dalam hal ini mendukung penerapan pendekatan keadilan restoratif.

Pengaturan pendekatan keadilan restoratif juga mulai terlihat dalam tujuan pemidanaan dan hal-hal yang wajib dipertimbangkan dalam pemidanaan yang

\footnotetext{
50 Rancangan Undang-Undang Kitab Undang-Undang Hukum Acara Pidana tahun 2014, Pasal 42 ayat (2), ayat (3) dan ayat (4)

51 Id.

52 Rancangan Undang-Undang Kitab Undang-Undang Hukum Pidana tahun 2015, Pasal 153 huruf d
} 
diatur oleh RKUHP tahun 2015. Dalam ketentuan Pasal 55 ayat (1) huruf c dan d RKUHP tahun 2015 disebutkan beberapa tujuan pemidanaan antara lain adalah:

1. menyelesaikan konflik yang ditimbulkan oleh tindak pidana, memulihkan keseimbangan dan mendatangkan rasa damai dalam masyarakat; dan

2. membebaskan rasa bersalah pada terpidana. ${ }^{53}$

Sementara itu, salah satu hal yang wajib dipertimbangkan dalam pemidanaan (pedoman pemidanaan) sebagaimana diatur dalam Pasal 56 ayat (1) huruf j RKUHP tahun 2015 adalah pemaafan dari korban dan atau keluarganya. ${ }^{54}$

Kembali mengacu pada bagian sebelumnya dalam tulisan ini yang berbicara mengenai perubahan perspektif mengenai tindak pidana dan keadilan dalam sistem peradilan pidana dan pendekatan keadilan restoratif, terlihat bahwa tujuan pemidanaan yang diatur dalam RKUHP telah memasukkan konsep pendekatan keadilan restoratif yang berorientasi pada pemulihan keseimbangan seperti semula sebelum terjadinya konflik. Selain itu, pemaafan dari korban atau keluarga menjadi salah satu hal yang wajib dipertimbangkan dalam penjatuhan pidana.

Perumusan ketentuan tersebut secara implisit memperlihatkan mulai diterimanya penerapan pendekatan keadilan restoratif yang pada dasarnya dapat pula dijadikan bahan pemikiran untuk menentukan kriteria atau kualifikasi tindak pidana yang dapat diselesaikan dengan menggunakan pendekatan keadilan restoratif.

\section{Penutup}

Persoalan tidak dilibatkannya partisipasi korban dan pelaku secara langsung (dalam hal ini diselesaikan oleh orang perorangan) dalam penyelesaian perkara pidana dengan dasar pemikiran negara melalui alat-alat kekuasannya mengambil alih proses penyelesaian perkara untuk mencegah terjadinya tindakan

53 Id.
54 Id. 
"main hakim sendiri" ternyata berujung pada ketidakpuasan korban dan pelaku terhadap sistem peradilan pidana. Pemikiran tersebut kini dihadapkan pada realita kebutuhan masyarakat atas mekanisme penyelesaian perkara pidana yang dianggap lebih mengakomodasi partisipasi dan aspirasi korban dan pelaku. Pendekatan keadilan restoratif yang dalam hal ini mengedepankan upaya melibatkan partisipasi korban dan pelaku secara langsung kemudian hadir sebagai respon atas persoalan tersebut.

Persoalan mendasar yang muncul dalam hal pendekatan keadilan restoratif ini hendak diterapkan adalah sebagai berikut:

1. Undang-undang belum secara jelas mengatur mengenai kekuatan hukum atas kesepakatan perdamaian antara pelaku dan korban dan kewenangan masingmasing subsistem baik di dalam maupun diluar sistem peradilan pidana untuk menerapkan pendekatan keadilan restoratif dalam hal terjadinya tindak pidana.

2. Ketidakjelasan kualifikasi tindak pidana yang dapat diselesaikan dengan menggunakan pendekatan keadilan restoratif.

Dengan demikian, apabila pendekatan keadilan restoratif ini ingin diterapkan, beberapa hal yang patut menjadi perhatian antara lain sebagai berikut:

1. Perlu adanya aturan hukum yang secara tegas mengatur mengenai kekuatan hukum atas kesepakatan perdamaian antara pelaku dan korban dan kewenangan masing-masing subsistem baik di dalam maupun diluar sistem peradilan pidana (polisi, jaksa, hakim, lembaga adat, masyarakat) untuk menerapkan pendekatan keadilan restoratif.

2. Kualifikasi tindak pidana yang dapat diselesaikan dengan menggunakan pendekatan tersebut harus ditentukan secara jelas.

3. Harmonisasi aturan hukum terkait kelembagaan, hukum pidana materil maupun hukum pidana formil mutlak diperlukan sehingga kegamangan petugas di lapangan tidak terjadi, subjektivitas penegak hukum dalam 
menerapkan pendekatan keadilan restoratif yang justru dapat menimbulkan persoalan baru juga dapat dihindari dan upaya pembaharuan hukum melalui pendekatan keadilan restoratif ini tidak menjadi kontra produktif.

\section{Daftar Pustaka}

Buku:

Abidin, A.Z. dan Andi Hamzah, Hukum Pidana Indonesia, Jakarta: Yarsif Watampone, 2010.

Bazemore, Gordon dan Lode Walgrave, Restorative Juvenile Justice: Repairing the Harm of Youth Crime, New York: Criminal Justice Press, 1999.

Braithwaite John and Heather Strang, Restorative Justice and Civil Society, 2001.

Galaway, Burt and Joe Hudson, Criminal Justice, Restitution and Reconciliation, New York : Criminal Justice Press, 1990.

Hamzah, Andi. Asas Asas Hukum Pidana, Jakarta: Rineka Cipta, 2003.

Hamzah, Andi. Hukum Acara Pidana Indonesia, Jakarta: Sinar Grafika, 2008.

Lamintang, P.A.F. Dasar Dasar Hukum Pidana Indonesia, Bandung : Citra Aditya Bakti, 1996.

Reksodiputro, Mardjono. Bunga Rampai Permasalahan Dalam Sistem Peradilan Pidana, Kumpulan Karangan Buku Kelima, Jakarta: Pusat Pelayanan Keadilan dan Pengabdian Hukum Lembaga Kriminologi Universitas Indonesia, 2007.

Reksodiputro, Mardjono. Kriminologi dan Sistem Peradilan Pidana, Kumpulan karangan Buku Kedua, Jakarta: Pusat Pelayanan Keadilan dan Pengabdian Hukum, Universitas Indonesia, 1994.

Remmelink, Jan. Hukum Pidana; Komentar atas Pasal-Pasal Terpenting dari Kitab Undang-Undang Hukum Pidana Belanda dan Padanannya dalam Kitab UndangUndang Hukum Pidana Indonesia, Jakarta: Gramedia Pustaka Utama, 2003.

Ritzer, George. Sosiologi: Ilmu Pengetahuan Berparadigma Ganda, Jakarta: PT Raja Grafindo Persada, 2004.

Satriyo, Rudi. Pelaksanaan Advokasi Terhadap Kekerasan Dalam Rumah Tangga Dalam Perspektif Hukum dan Hak Asasi Manusia, Balitbang HAM - Departemen Hukum dan HAM RI, 2006.

Strang, Heather and John Braithwaite, Restorative Justice: Philosophy to Practice, Burlington: Ashage Publishing Company, 2000.

Sudarto, Hukum Pidana I, Semarang: Yayasan Sudarto d/a Fakultas Hukum Undip Semarang.

Zehr, Howard. Changing Lenses: A New Focus for Crime and Justice, Scottdale, PA : Herald Press, 1990.

Zulfa, Eva Achjani. Reparasi dan Kompensasi Korban Dalam Restorative Justice, Jakarta: Lembaga Perlindungan Saksi dan Korban dan Departemen Kriminologi FISIP UI, 2011. 
Willemsens, Jolien, Repotioning Restorative Justice, Devon: Willam Publishing, 2003.

Makalah:

Naibaho, Nathalina. Perkembangan Teori-Teori Hukum Pidana: Restorative Justice, Pascasarjana Fakultas Hukum Universitas Indonesia, 2010.

Zulfa, Eva Achjani. Konsep Dasar Restorative Justice, disampaikan pada Pelatihan Hukum Pidana dan Kriminologi "Asas-Asas Hukum Pidana dan Kriminologi serta Perkembangannya Dewasa ini", Universitas Gajah Mada, Yogyakarta, 2327 Februari 2014.

Zulfa, Eva Achjani. Mediasi Penal: Perkembangan Kebijakan Hukum Pidana, Pascasarjana Fakultas Hukum Universitas Indonesia.

Disertasi:

Eva Achjani Zulfa, Keadilan Restoratif di Indonesia (Studi Tentang Kemungkinan Penerapan Pendekatan Keadilan Restoratif Dalam Praktek Penegakan Hukum Pidana), Ringkasan Disertasi, Fakultas Hukum Pogram Studi Ilmu Hukum Kekhususan Sistem Peradilan Pidana Universitas Indonesia, 2009.

Peraturan Perundang-undangan:

Economic and Social Council (ECOSOC) United Nations Resolution 2002/12 Basic principles on the use of restorative justice programmes in criminal matters

Indonesia, Undang Undang Tentang Hukum Acara Pidana, UU Nomor 8 Tahun 1981, Lembaran Negara No. 76 Tahun 1981 Tambahan Lembaran Negara No. 3209 (KUHAP). , Undang Undang Tentang Kepolisian, UU Nomor 2 Tahun 2002, Lembaran Negara No. 2 Tahun 2002 Tambahan Lembaran Negara No. 4186. , Undang Undang Tentang Kejaksaan, UU Nomor 16 Tahun 2004, Lembaran Negara No. 67 Tahun 2004 Tambahan Lembaran Negara No. 4401. , Undang Undang Tentang Kekuasaan Kehakiman, UU Nomor 48 Tahun 2009, Lembaran Negara No. 157 Tahun 2009 Tambahan Lembaran Negara No. 5076.

Rancangan Undang Undang Kitab Hukum Pidana.

Rancangan Undang-Undang Kitab Undang-Undang Hukum Acara Pidana.

Putusan Pengadilan:

Putusan Mahkamah Agung No. 2127 K/Pid/2001

Putusan Mahkamah Agung No. 15 K/Pid/2007

Internet:

http://www.restorativejustice.org/

Jecky Tengens, Pendekatan Restorative Justice dalam Sistem Peradilan Pidana Indonesia,http://www.hukumonline.com/berita/baca/t4e25360a422c2/ 
pendekatan-irestorative-justice-i-dalam-sistem-pidana-indonesia-broleh-jecky-tengens--sh-, diakses tanggal 28 November 2014.

United Nations Office on Drugs and Crime, Handbook on Restorative Justice Programmes, New York : United Nation, 2006, http://www.unodc.org/ pdf/criminal justice/06-56290 Ebook.pdf, diakses tanggal 15 Mei 2014. 